\title{
The abbey of Savigny (Manche) in Britain and Ireland in the 12th century : three overlooked documents*
}

The role played in the spread of new monasticism in the British Isles by the Norman abbey of Savigny, head of the duchy's only native monastic congregation, is one that has already attracted much scholarly attention ${ }^{1}$. Founded at the beginning of the 12 th century on the volatile frontier of three major principalities (Normandy, Brittany and Maine), Savigny quickly gave birth to a filiation that, by the time of its eventual merger with the Cistercian Order, counted some fourteen houses throughout England, Wales and southern Ireland. The aim of this article is not to look again in detail at the mechanics of this expansion, nor to consider such questions as the role played by Savigny's British houses in its eventual amalgamation with Cîteaux ${ }^{2}$, but rather to

\footnotetext{
* For their help with various matters, I am extremely grateful to Dr Alison Hudson of the British Library, to Sarah Prescott, Literary Archivist at Leeds University Library, to Dr Vanessa Wilkie, Curator of Medieval Manuscripts and British History at the Huntington Library, California, and to Julie Deslondes, Director of the Archives départementales du Calvados. I am also grateful to the two anonymous reviewers for their comments. Naturally, any errors that remain are my own. This article is dedicated to the memory of Christophe Mauduit.

${ }^{1}$ Savigny-le-Vieux, Manche, cant. Saint-Hilaire-du-Harcouët. Besides the various mentions of Savigny in the wider literature, see such specific studies as B. POULlE, « Savigny and England », in D. BATES and A. CURRY (dir.), England and Normandy in the Middle Ages, London, Hambledon Press, 1994, p. 159-168 ; J. BURTON, «L'arrivée de l'ordre Savigniac en Angleterre et au pays de Galles », in V. GAZEAU and B. GALBRUn (dir.), L'abbaye de Savigny (1112-2012). Un chef d'ordre anglo-normand (Actes du colloque de Cerisy-la-Salle, 3-6 octobre 2012), Rennes, Presses universitaires de Rennes, forthcoming.

${ }^{2}$ G. Constable, «The affiliation of Savigny », in M. Dutton, D. La Corte and P. Lockey (dir.), Truth as gift : studies in medieval Cistercian history in honor of John R. Sommerfeldt, Kalamazoo, MI,
} Cistercian Publications, 2004, p. 43-88 (esp. p. 57-61). 
examine three important documents that have yet to receive the full attention they deserve. Of these three, two relate to the Savigniac houses at Dublin, Buildwas and Basingwerk. Although not unknown to scholars, especially those working outside France, the texts have long been cited with reference to an inadequate antiquarian printing. The document from which this printing was made was separated shortly thereafter from the private collection of which it once formed a part, with previous attempts to relocate it having proved unsuccessful. Not only does it still survive, however, but it is in fact today housed at the British Library, where it has lay hidden in plain sight since 1851. Furthermore, an original charter on which it is partly based, and which has never before been the subject of scholarly examination, is now to be found at the Huntington Library in San Marino, California. Taken together, this article will show how these texts shed light not only on a key episode in the story of the Savigniac filiation in Britain and Ireland, but also offer an unparalleled (and previously unnoticed) snapshot of life at the abbey of Savigny itself, especially in the period (hitherto little explored) immediately following the Cîteaux merger. As for the third document, which relates to the Savigniac house of Stratford Langthorne in Essex, this was witnessed and sealed by two Cistercian abbots, one of whom was Jocelin, abbot of Savigny (1165-1178). His seal has not been previously noticed by scholars, despite the fact that it is among the earliest (perhaps the earliest) to survive from Cistercian Normandy.

Before examining these documents in more detail, however, let us begin by briefly setting them in their wider historical and archival context. The early history of Savigny, which has already been examined in detail elsewhere, need not detain us to 
any great degree ${ }^{3}$. Founded in 1112 by the hermit Vitalis $(\dagger 1122)$, Savigny was one of a number of religious houses born of the intellectual and religious fervour that gripped the Latin West at the turn of the 12th century. Its early abbots, in particular Geoffrey de Bayeux (1122-1138/9) and Serlo de Vaubadon (1140-1153) ${ }^{4}$, played a key role in formalising the primitive monastic community and expanding its filiation, which, by the middle of the 12th century, counted more than thirty houses throughout northern France and the British Isles ${ }^{5}$. Although impressive, such rapid growth was not without its complications, and Abbot Serlo soon found himself confronted with trying to manage restive daughter houses that, by the $1140 \mathrm{~s}$, were themselves struggling to negotiate the increasingly bitter conflict between King Stephen (1135-1154) and the Empress Mathilda $(1102-1167)^{6}$. The debate surrounding when and why Serlo decided to merge his congregation with that of Cîteaux has been both long and contentious, but it is now generally accepted that the incorporation itself took place in 1147, with Savigny becoming a daughter house of the abbey of Clairvaux ${ }^{7}$. There is no need to dwell here on the long-term impact of this amalgamation upon either

\footnotetext{
${ }^{3}$ For St Vitalis and the history of Savigny during its first decades after foundation, see J. VAN MoOLENBROEK, Vital l'ermite, prédicateur itinérant, fondateur de l'abbaye normande de Savigny, A.M. NAMBOT (trans.), Assen, Van Gorcum, 1990.

${ }^{4}$ Vaubadon, Calvados, cant. Trévières.

${ }^{5}$ For further discussion of Geoffrey and Serlo, see H. FEISS, R. PEPIN and M. O'BRIEN, The lives of monastic reformers 2: Abbot Vitalis of Savigny, Abbot Godfrey of Savigny, Peter of Avranches, and Blessed Hamo, Collegeville, MN, Cistercian Publications, 2014, p. 15-31.

${ }^{6}$ G. CONSTABLE, « The affiliation of Savigny... », op. cit., p. 57-61.

${ }^{7}$ For the controversy, see in particular C. BERMAN, The Cistercian evolution: the invention of a religious order in twelfth-century Europe, Philadelphia, PA, University of Pennsylvania Press, 2000, p. 142-148. As a corrective to Berman's views, see F. SWIETEK and T. DENEEN, « The date of the merger of Savigny and Cîteaux reconsidered », Revue d'histoire ecclésiastique, 101, 2006, p. 547-574.
} 
Savigny or the wider Cistercian Order, but it is worth noting that the merger did not prevent Savigny from retaining peculiar practices for itself, especially in the realm of finance $^{8}$, nor from overseeing matters concerning its affiliates, a fact to which the documents discussed below bear witness.

These documents also testify to the fact that, despite the wholesale destruction of its buildings and the loss of much of its library, the abbey of Savigny is one of the few religious institutions of western Normandy for which an impressive corpus of largely unpublished medieval material survives. Notwithstanding the destruction by fire in 1944 of an early 13 th-century cartulary that contained over 680 documents, there still exist four more or less complete copies of this manuscript as well as over 1,700 original charters, mainly dating from the 12th and 13th centuries, which are largely conserved at the Archives nationales in Paris. A copy of a second cartulary containing 568 acts, the original of which was likewise destroyed in 1944, also survives ${ }^{9}$. Outside the diplomatic material, there are also vitae of the abbey's saints ${ }^{10}$, a set of miracles ${ }^{11}$, and

\footnotetext{
${ }^{8}$ J. Buнот, «L'abbaye normande de Savigny, chef d'ordre et fille de Cîteaux », Le Moyen Âge, 46, 1936, p. 249-264 ; B. HILL, English Cistercian monasteries and their patrons in the twelfth century, Urbana, IL, University of Illinois Press, 1968, p. 80-115 ; F. SWIETEK and T. DenEEN, «'Et inter abbates de majoribus unus' : the abbot of Savigny in the Cistercian constitution, 1147-1243 », in M. DUtTON, D. LA CORTE and P. LOCKeY (dir.), Truth as gift..., op. cit., p. 89-118.

${ }^{9}$ For full discussion, see B. PoulLE, «Les sources de l'histoire de l'abbaye cistercienne de Savigny au diocèse d'Avranches », Revue Mabillon, n. s., 7 (= 68), 1996, p. 105-125 ; R. AlLEN, «Les chartes originales de Savigny des origines jusqu'au XIII ${ }^{\mathrm{e}}$ siècle (1112-1202) », in V. GAZEAU and B. GALBRUN (dir.), L'abbaye de Savigny..., op. cit., forthcoming.

${ }^{10}$ E.-P. SAuvage, «Vitae BB. Vitalis et Gaufridi, primi et secundi abbatum Saviniacensium», Analecta Bollandiana, 1, 1882, p. 355-410; ID., «Vitae B. Petri Abrincensis et B. Hamonis monachorum coenobii Saviniacensis in Normannia », Analecta Bollandiana, 2, 1883, p. 475-560.
} 
the so-called Chronicon Savigniacense ${ }^{12}$. Together, this collection represents one of the great wonders not only of Norman but of medieval French history. The corpus of original charters alone, which includes acts issued by individuals at every level of medieval society, not to mention over 300 seals $^{13}$, is larger than that for Cîteaux itself, for Prémontré, for Clairvaux, or indeed for any other of the more famous French centres of 12th-century reformed Benedictine life. Needless to say, these texts are critical for placing the documents discussed in this article, along with the people and events they describe, in their wider context.

As the introduction above suggests, individual Savigny charters (or handfuls thereof) can also be found at institutions outside of northern France. Two of the most important are the subject of this article, and relate to the process by which the abbeys of St Mary's, Dublin, and Basingwerk, in north Wales, became dependencies of the abbey of Buildwas in Shropshire. The first is a late 12th-century roll, which is today housed at the British Library (Appendix, $\mathbf{n}^{\mathbf{0}} \mathbf{1}$ ). Written in two different hands, and classified

11 J. BACHELIER, «Miracles et miraculés au milieu du XIII ${ }^{\mathrm{e}}$ siècle d'après le Livre des Saints de l'abbaye de Savigny », Revue de l'Avranchin et du Pays de Granville, 88, 2011, p. 21-59. The author is in the process of preparing a critical edition of this text.

12 This text has long been known by a wholly inadequate 17 th-century printing : É. BALUZE (ed.), «Chronicon Savigniacense », in Stephani Baluzii miscellaneorum liber primus [-septimus], 7 vol., Paris, 1678-1715, t. II, p. 310-323. For further discussion and a critical edition, see R. ALLEN, « The annals and history of the abbots of Savigny: a new edition of the so-called Chronicon Savigniacense (12th-14th c.) », Cîteaux - Commentarii cistercienses, 68, 2017, p. 9-73.

${ }^{13}$ For discussion of these seals, not including that of Abbot Jocelin, see R. ALLEN, « Les sceaux du chartrier de l'abbaye de Savigny de 1112 à 1300 », in C. BLANC-RIEHL, J.-L. CHASSEL and C. MANEUVRIER (dir.), Apposer sa marque : le sceau et son usage (autour de l'espace anglo-normand) (Actes du colloque de Cerisy-la-Salle, 4-8 juin 2013), forthcoming. 
by some as a cartulary ${ }^{14}$, it contains the texts of five charters, ranging in date from 26 November 1156 to $1190-1192$, and was once sealed with three seals, of which remnants of only two survive. Its existence was first brought to light in the first half of the 19th century by Joseph Hunter (1783-1861), who consulted the roll in 1806 at Broomhead Hall in Yorkshire ${ }^{15}$, where it formed part of the collection of the antiquarian John Wilson (1719-1783), who had himself acquired it from Dr Cox Macro (bef. 1683-1767) ${ }^{16}$. The John Wilson of Broomhead Archive is today housed among the Special Collections of Leeds University Library ${ }^{17}$, where it was deposited following its sale in 1953 by the Wilson family, who had themselves repurchased the collection at the end of the 19th century from Sir Thomas Phillipps (1792-1872), to whom it had been sold in $1843^{18}$.

Unsurprisingly, such a peripatetic history means that the Wilson collection is not today as Joseph Hunter first saw it, with certain items having become separated from the whole. Thus, a charter of Robert de Sigillo, bishop of London (1141-1150), which was likewise printed by Hunter following his visit to Broomhead ${ }^{19}$, is today found at

\footnotetext{
${ }^{14}$ G.R.C. DAVIS, Medieval cartularies of Great Britain and Ireland, C. BREAY, J. HARRISON and D.M. SMITH (ed.), London, The British Library, 2010, p. 21.

${ }^{15}$ J. HUNTER, Ecclesiastical documents viz. I. A brief history of the bishoprick of Somerset II. Charters from the library of Dr Cox Macro, London, John Bowyer Nichols, 1840, $\mathrm{n}^{\circ}$ III, p. 51-54.

${ }^{16}$ For Cox Macro, see S. BREWER, « Macro, Cox (bap. 1683, d. 1767)», Oxford Dictionary of National Biography, Oxford University Press, 2004.

${ }^{17}$ Leeds University Library, Special Collections, ms 295.

${ }^{18}$ A. MunBy, The dispersal of the Phillipps Library, Cambridge, Cambridge University Press, 1960, p. $51-52$.

${ }^{19}$ J. HUNTER, Ecclesiastical documents..., op. cit., no II, p. 50-51.
} 
Stafford in the William Salt Library, which acquired it as part of Salt's collection in $1872^{20}$. As for our roll, it was put up for auction at Puttick and Simpson's on 19 August 1851 as Lot 39 of a small collection of medieval charters, whence it was purchased by trustees of the British Museum ${ }^{21}$. Its whereabouts between 1806 and 1851 are unclear. The small collection of which it formed a part in 1851 is presented in the catalogue simply as an addendum to the first day of sales of an « extensive and valuable library of a gentleman deceased », but the nature of this larger collection, which was mainly comprised of early-modern printed materials, coins and artwork, suggests the two were unrelated. One possible explanation is that the roll passed by means unknown from John Wilson to Thomas Noel Hill (1770-1832), 2nd Baron Berwick, whose large collection was sold due to bankruptcy in 1827 and 1829 . He has been linked with other charters purchased by the British Museum during the 1851 sale $^{22}$, and the proximity of his family seat at Attingham Park to Buildwas Abbey, a little over ten kilometres to the southeast, is certainly good enough reason to suggest he might have had an interest in items relating to it, even if the fact that no discernible mention of the roll can be found in the catalogue of the 1827 sale serves somewhat to undermine this idea (no copy of the 1829 catalogue seemingly survives) ${ }^{23}$. Whatever

\footnotetext{
${ }^{20}$ A critical edition can be found in English episcopal acta. 15, London 1076-1187, F. NEININGER (ed.), Oxford, Oxford University Press, 1999, n 48. I am grateful to Dominic Farr, Assistant Librarian of the William Salt Library, for confirming that there is no further information with regards to the means by which William Salt acquired this charter.

${ }^{21}$ Puttick and Simpson, Catalogue of Sales, no 225, 19 August 1851, Addenda.

22 «Ancient Montgomeryshire charters», Collections Historical and Archaeological Relating to Montgomeryshire and its Borders, 22, 1888, p. 1-8, at p. 1.

${ }^{23}$ Attingham Hall, near Shrewsbury, in the county of Salop. Superb furniture; costly service of silver and gilt plate, ..., which will be sold by auction, by Mr. Robins, of Warwick House, Regent Street, at the
} 
the case may be, the arrival of the charter roll at the British Library seems to have escaped almost all notice, a fact not helped by catalogue entries that are either incorrect or cursory ${ }^{24}$, with the result that those trying to locate the document in the modern era have been unable to find it $^{25}$.

The effect, however, has not been to obscure the text from scholars interested in English, Welsh and Irish monastic history, who have long been aware of the Hunter printing $^{26}$, but rather to prevent knowledge of it spreading beyond British shores. The charters contained in the roll have thus escaped the attention of historians with an interest in Savigny itself, despite the fact that these texts are just as important for the light they shed on the abbey community in the mid-12th century as on its dealings magnificent mansion, Attingham Hall, ... on Monday, the 30th of July, 1827, and fifteen following days, ... by order of the Right Honourable Lord Berwick, London : printed by T. Brettell, [1827].

${ }^{24}$ The roll is mistakenly listed as an Additional Charter in the catalogue of additions for the year 1851 (Catalogue of additions to the manuscripts in the British Museum in the years MDCCCXLVIIIMDCCCLIII, London, British Museum, 1868, p. 283), leading to the occasional incorrect reference to it as Add. Ch. 8075 (W. DE GRAY BIRCH, A history of Margam Abbey: derived from the original documents in the British Museum, H.M. Record Office, the Margam Muniments, etc., London, Bedford Press, 1897, p. 333), while the British Library index of manuscripts simply refers to it as «Add. 8075 », and describes the roll in such a way as to hide its real significance : « Roll of charters conc. affiliation to [Buildwas], of St Mary's Dublin, and Basingwerk Abbeys, late 12 cent. (Billewas) » (Index of manuscripts in the British Library, 10 vol., Cambridge, Chadwyck-Healey, 1984-, t. II, p. 177).

${ }^{25}$ See, for example, A. GWYNN, « The origins of St. Mary’s Abbey, Dublin », The Journal of the Royal Society of Antiquaries of Ireland, 79, 1949, p. 110-125, at p. 116 n. 23.

26 For typical examples, see D. WILliAMs, «Basingwerk Abbey», Cîteaux - Commentarii cistercienses, 32, 1981, p. 89-90, at p. 90 n. 16 ; M.T. FlANAGAN, The transformation of the Irish church in the twelfth and thirteenth centuries, Woodbridge, Boydell Press, 2010, p. 157. 
with its British and Irish daughters. Thus, the extensive witness list of the first act, which was issued on 26 November 1156 by Abbot Richard de Courcy (bef. 20 April 1154-1158), provides us with an unparalleled snapshot of the community in the first decade after Savigny's incorporation with Cîteaux. Eleven officials are mentioned in total, many of whom, along with the positions they held, are known only by this document. Such is the case with the prior Arraud, who must have served for a short period between his predecessor, Richard, whose last appearance dates to $1154 / 5^{27}$, and his successor, Roger, referred to elsewhere as Roger d'Aunay (Alneto), who the second act on the roll shows was in post from $1157^{28}$. Likewise, not only is Robert the novice master (magister noviciorum) otherwise unknown, but this is one of only two references to this particular office before 1250 , and the only one to survive in the diplomatic evidence ${ }^{29}$.

Most significant, however, is the appearance among the witnesses of Hugh the infirmarian (infirmarius), Christian the guest-master (hospitalis) and William the gate-keeper (portarius). No other mention of these offices, or of the individuals who held them, is known outside the acts of 1156 and 1157 recorded by the charter roll. That such positions existed at Savigny at this time is of particular interest, as it suggests a community both willing and able to accommodate guests. As a Cistercian

\footnotetext{
${ }^{27} \mathrm{He}$ appears among the witnesses of an act of Guido the forester that also refers to Abbot Richard de Courcy (Paris, Arch. nat., L 967, n 93).

${ }^{28}$ Besides his mention in the second act of the charter roll, Roger appears in two acts of Peter de SaintHilaire dated 17 June 1157 (BnF, ms nouv. acq. lat. 2292, $n^{\text {os }} 1$ et 2) ; a charter notice of $1158-1161$ (Paris, Arch. nat., L 969, $\mathrm{n}^{\circ}$ 347) ; and acts of William de Passavant, bishop of Le Mans, and Bermon,

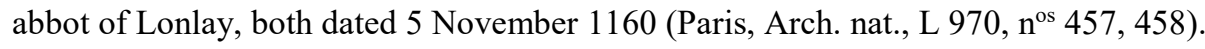

${ }^{29}$ For discussion, see R. ALLEN, « Les chartes originales... », op. cit., forthcoming.
} 
house, Savigny was supposed to be withdrawn from the world, but hospitality was nevertheless an important element of Cistercian life. According to the Charter of Charity, no new abbey was to be founded without such places as a guest-house and a gate-keeper's cell ${ }^{30}$, and it is not impossible that these had been introduced at Savigny by the prior Theobald, who had been sent from Clairvaux in the wake of the merger with Cîteaux to introduce the monks to Cistercian practices ${ }^{31}$. Hospitality was also especially important for Cistercian borderland institutions, which often found themselves serving as useful mustering points for those involved in military campaigns or important gatherings ${ }^{32}$. Twelfth-century Savigny was certainly no stranger to such events, since in 1172 it hosted the first round of negotiations between papal legates and Henry II (1154-1189) in relation to the murder of Thomas Becket ${ }^{33}$. Of course, the abbey would have also received a steady stream of regular visitors, both male and female. Some would have come seeking to be healed by Savigny's

\footnotetext{
${ }^{30}$ Les plus anciens textes de Cîteaux : sources, textes et notes historiques, J. DE LA CROIX BOUTON and J.-B. VAN DAMmE (ed.), Achel, Abbaye cistercienne, 1974, p. 121. For discussion of these principles in practice, see J. BERGER, Die Geschichte der Gastfreundschaft im hochmittelalterlichen Mönchtum : die Cistercienser, Berlin, Akademie Verlag, 1999, p. 190-212.

${ }^{31}$ For Theobald's time at Savigny, see R. ALLEN, «À la recherche d'un atelier d'écriture de la Normandie cistercienne : le scriptorium de l'abbaye de Savigny (XII $-\mathrm{XIII}^{\mathrm{e}}$ siècles) », in A. BAUDIN and L. MoRelle (dir.), Les pratiques de l'écrit dans les abbayes cisterciennes (XII -milieu du XVI Produire, échanger, contrôler, conserver, Paris, Somogy éditions d'art, 2016, p. 31-54, at p. 42.

32 J. KERR, «Cistercian hospitality in the later Middle Ages », in J. BURTON and K. StÖBER (dir.), Monasteries and society in the British Isles in the later Middle Ages, Woodbridge, Boydell Press, 2008, p. 25-39, at p. 29-31 ; E. JAMROZIAK, Survival and success on medieval borders : Cistercian houses in medieval Scotland and Pomerania from the twelfth to late fourteenth century, Turnhout, Brepols, 2011, p. $62-67$.

${ }^{33}$ F. SWIETEK, « King Henry II and Savigny », Cîteaux - Commentarii cistercienses, 38, 1987, p. 14-23.
} 
earliest «saints », whose relics were then housed in the chapel of St Catherine ${ }^{34}$, while others, such as Guido the forester, who visited Savigny on his way back to Rennes from England in the mid-1150s $\mathrm{s}^{35}$, would have used the abbey as a convenient stopover point during a long journey.

As for those who would have been on hand to greet visitors like Guido, a detailed examination of Savigny's other charters allows us not only further to identify the officials mentioned in the act of 26 November 1156, but also to paint a picture of the wider community of which they formed a part. Thus, a charter recording events of 16/17 June 1157 shows that Geoffrey the sub-prior was without doubt the same individual as Geoffrey de Rennes, who was still at the abbey in the mid-1170s ${ }^{36}$, and that the cellarers Robert and Geoffrey were known as Robert de Tourailles and Geoffrey de Saint-Aubin ${ }^{37}$. Their contemporaries included the celebrated Peter

\footnotetext{
${ }^{34}$ For discussion of those who made the pilgrimage to Savigny in the 13 th century, see J. BACHELIER, « Miracles et miraculés... », op. cit., p. 21-59.

35 «Universis sancte Dei ecclesie fidelibus, Guido forestarius, salutes tam futuris quam presentibus. Notum fieri volo quod ego dedi ecclesie et monachis Savigneii in perpetuam elemosinam, pro salute anime mee et omnium antecessorum ac successorum meorum, totum pratum de Fonte Theois, quod de dominico meo erat, et landulam juxta illud, sicut fossatum circa illa signatum est ..., excepta recognitione XVIII denariorum Andegavorum mihi singulis annis reddendorum. Postea vero ego rediens ab Anglia, dum venissem Savigneium, dedi eidem ecclesie Savig(neii) et monachis XII denarios de supradicta recognitione ... », Paris, Arch. nat., L 967, nº 93.

${ }^{36}$ BnF, ms nouv. acq. lat. 1022, p. 158-159 (act of Richard de Bohon, bishop of Coutances, aft. 3 Feb $1173-1174 / 5)$

37 « Facta est autem hec nostra donatio atque concessio ... anno ab incarnatione Domini M. C. ${ }^{o}$ LVII $^{\circ}$, $\mathrm{XVI}^{\circ} \mathrm{k}($ alendas$)$ julii ... Iterum autem in crastino est recapitulata atque confirmata in eodem capitulo Savigneii. Teste : Rogero de Alneto priore, et Gaufrido de Redonis subpriore, et Roberto de Turaliis
} 
d'Avranches and Hamon de Landecot († 30 April 1173), who would both go on to become part of Savigny's small pantheon of saints ${ }^{38}$, as well as eight other individuals whose toponymics show they enjoyed connections to local centres of power in the frontier zone in which the abbey was located, and perhaps also to the families that controlled them (Table 1). Outside of the monastic precinct, the monks would have relied on an expanding network of lay brothers (conversi) recruited to support them. The identities of these individuals, along with their activities, are generally unknown to us at this time ${ }^{39}$, but the movements of the lay brother Gilbert show him clearly serving as a travelling companion to the monks, as is known to have been the case elsewhere in cellarario, et Gaufrido de Sancto Albano subcellarario ... », BnF, ms nouv. acq. lat. 2292, $\mathrm{n}^{\text {os }} 1$ et 2 (act of Peter de Saint-Hilaire).

${ }^{38}$ For their vitae, see above n. 10. Peter, who was renowned for his strictness, appears among the witnesses of only one charter (Paris, Arch. nat., L 979, n 112). Hamon de Landecot (Ille-et-Vilaine, cant. Saint-Brice-en-Coglès, cne. Saint-Étienne-en-Coglès), who served as confessor to Henry II, appears somewhat more frequently in the diplomatic evidence : Paris, Arch. nat., L 966, nº 27 (act of Guy de Laval, 1157 - 1161) ; L 969, no 403 (act of Robert de Vitré, 1 April 1161) ; L 970, nos 457, 458 (acts of William de Passavant, bishop of Le Mans, and Bermon, abbot of Lonlay, 5 Nov 1160); L 973, $\mathrm{n}^{\circ} 829$ (act of the chapters of Savigny and Mortain, 1161/2 - 1165); L 975, $\mathrm{n}^{\circ} 1075$ (act of Ralph II de Fougères, 1163/4) ; Caen, Arch. dép. Calvados, F 5690, fol. 140v (act of Robert de Vitré, 1158 1161 ) ; Bibl. mun. Rouen, ms. Leber 5636, no 4 (charter notice, Dec 1163) ; P.-H. MoRICE, Mémoires pour servir de preuves à l'histoire ecclésiastique et civile de Bretagne, 3 vol., Paris, Charles Osmont, 1742-1746, t. I, col. 606-607 (act of Ralph II de Fougères for the abbey of Rillé, 1150 - 1157); The cartulary of Missenden Abbey, J.G. JENKINS (ed.), 3 vol., London, Buckinghamshire Archaeological Society 1938-1962, t. III, nº 702, p. 109 (act of Ralph II de Fougères for the abbey of Missenden, 1168 $-1173)$.

${ }^{39}$ For discussion of the lay brother community at Savigny, see R. ALLEN, «Life and death in a medieval monastery: the case of the Cistercian abbey of Savigny (1112-c. 1250)», The Journal of Medieval Monastic Studies, 7, 2018, p. 79-125, at p. 94-98. 
the Cistercian world ${ }^{40}$, since he can be found at Ernée with Prior Roger d'Aunay (aft. 26 Nov. 1156 - bef. Dec. 1163) and the monk Peter de Châteaugiron in $1160^{41}$; at Le Mans on 5 November that same year with the same Prior Roger and Hamon de Landecot ${ }^{42}$; and at Saint-Lô on 18 February 1163 with Abbot William II (1161/21165 ) and the monk Ingetulfus ${ }^{43}$.

Thanks to the survival of a related document that has essentially escaped all scholarly attention, we are also able to say something about Savigny's diplomatic practices in the years immediately following its merger with Cîteaux. Conserved today at the Huntington Library in San Marino, California, the document in question is the original charter issued by Abbot Richard on 26 November 1156 (Appendix, $\mathbf{n}^{0}$ 2). Originally acquired either by Sir Thomas Egerton (1540-1617), or by one of his descendants, the charter was purchased in 1917 by Henry E. Huntington (1850-1927) as part of the massive collection of Egerton family papers, also known as the Ellesmere Collection ${ }^{44}$. In terms of its content, it shows that the copyist of the British Library roll was faithful in his task, and neither amended nor omitted anything of great importance. As for its physical characteristics, the charter is written on an almost square piece of parchment in a large, regular, proto-gothic hand (fig. 2). The

\footnotetext{
${ }^{40}$ For other examples of lay brothers serving as travelling companions to Cistercian abbots and monks, see J. FRANCE, Separate but equal : Cistercian lay brothers, 1120-1350, Collegeville, MN, Cistercian Publications, 2012, p. 8-9.

${ }^{41} \mathrm{BnF}$, ms. nouv. acq. lat. 1022 , p. $378-379$. The act is misdated 1150 by the cartulary scribe.

${ }^{42}$ Paris, Arch. nat., L 970, no 457 (act of William de Passavant, bishop of Le Mans).

${ }^{43}$ Ibid., L 970, $\mathrm{n}^{\circ} 548$ (act of Richard de Bohon, bishop of Coutances).

${ }^{44}$ The collection contains some 13,000 pieces, ranging in date from 1150 to 1803 . A finding aid can be consulted at $<$ http://pdf.oac.cdlib.org/pdf/huntington/mss/egerton.pdf $>$ (accessed 7 October 2017).
} 


\begin{tabular}{|c|c|c|c|}
\hline Name & Place & Date $^{45}$ & Reference \\
\hline Arraud, prior ${ }^{46}$ & - & 26 Nov 1156 & Appendix, $\mathrm{n}^{\circ} 1$ \\
\hline Geoffrey de Rennes & Ille-et-Vilaine, chef-lieu de cant. & 26 Nov 1156 & Appendix, $\mathrm{n}^{\circ} 1$ (see also above $\mathrm{n} .36$ ) \\
\hline Hamon de Landecot & $\begin{array}{l}\text { Ille-et-Vilaine, cant. Saint-Brice-en-Coglès, cne. } \\
\text { Saint-Étienne-en-Coglès }\end{array}$ & See above n. 38 & See above n. 38 \\
\hline Henry de Lignières & $\begin{array}{l}\text { Perhaps Lignières-Orgères, Mayenne, cant. } \\
\text { Villaines-la-Juhel }\end{array}$ & $1158-1161$ & Arch. dép. Calvados, F 5690, fol. 140v \\
\hline Hugh, sacristan & - & 26 Nov 1156 & Appendix, $\mathrm{n}^{\circ} 1$ \\
\hline Humphrey, chanter & - & 26 Nov 1156 & Appendix, $\mathrm{n}^{\mathrm{o}} 1$ \\
\hline John de Combourtillé & Ille-et-Vilaine, cant. Fougères-1 & Oct 1155 & Rouen, Bibl. mun., ms Leber 5636, $\mathrm{n}^{\circ} 3$ \\
\hline John de la Tannière & $\begin{array}{l}\text { Mayenne, cant. Gorron, cne. Saint-Berthevin-la- } \\
\text { Tannière }\end{array}$ & $\begin{array}{l}\text { aft. Nov } 1156-\text { bef. } \\
\text { Dec } 1163\end{array}$ & BnF, ms nouv. acq. lat. 1022 , p. $404-405$ \\
\hline Peter d'Avranches & Manche, chef-lieu de cant. & See above n. 38 & See above n. 38 \\
\hline Robert de Tourailles, cellarer & Perhaps Orne, cant. Athis-de-l'Orne & 26 Nov 1156 & Appendix, $\mathrm{n}^{\circ} 1$ (see also above $\mathrm{n} .37$ ) \\
\hline Roger d'Aunay & Aunay-sur-Odon, Calvados, chef-lieu de cant. & Nov 1156 & BnF, ms nouv. acq. lat. 1022 , p. $26-28$ \\
\hline Stephen du Mesnil-Ameland & Manche, cant. Le Mortainais, cne. Villechien & $1158-1161$ & Arch. nat., L 969, n 347 \\
\hline William, cellarer & - & 26 Nov 1156 & Appendix, $\mathrm{n}^{\circ} 1$ \\
\hline William, gate-keeper & - & 26 Nov 1156 & Appendix, $\mathrm{n}^{0} 1$ \\
\hline William de Milly & Manche, cant. Saint-Hilaire-du-Harcouët & 16 June 1157 & BnF, ms nouv. acq. lat. $2292, \mathrm{n}^{\circ} 1$ \\
\hline William of Neath & Wales, West Glamorgan & $1158-1161$ & Arch. dép. Calvados, F 5690, fol. 140v \\
\hline
\end{tabular}

Table 1 The community at Savigny in the late 1150s/early 1160s

${ }^{45}$ This date (or dates) refer(s) to the document cited in the column to the right. It does not indicate the total period the monk in question can be traced at the abbey.

${ }^{46}$ Succeeded as prior by Roger d'Aunay at some point after 26 Nov 1156 and before 17 June 1157. 
difficulties in identifying Savigny scribes of this period have already been discussed in detail elsewhere ${ }^{47}$, and while around thirty original Savigny charters survive for the period between 1147 and 1157 (Table 2), with many written in equally large and regular hands, none contain all the features that serve to distinguish that of the act now in California ${ }^{48}$. However, given that the charter was issued in the name of Abbot Richard, rather than a third party, such as a local bishop or magnate, it would be surprising if the scribe was not a Savigny monk.

As for its sealing, which is sur double queue, neither the parchment tag nor the seal itself has survived ${ }^{49}$. This loss is a great shame, since the only known (and previously unnoticed) printed description of the charter, which was published following a survey carried out by the Historical Manuscripts Commission before the Egerton family papers were sold to Henry Huntington, reveals that the seal still existed towards the end of the 19th century. Seemingly then in excellent condition, it is described as being oval and of brown wax, with a field showing a hand holding a pastoral staff, surrounded by the legend + SIGILLVM ABBATIS SAVIGNEII ${ }^{50}$. As we shall see,

\footnotetext{
${ }^{47}$ R. ALLEN, « Les chartes originales ... », op. cit., forthcoming.

${ }^{48}$ These include a lower case $\mathbf{g}$ with a descender that is formed of a large curving stroke, which is then completed by a second, lighter stroke from the end back up towards the line, creating a closed bowl ; a long-form $\mathbf{s}$ that consists of a tall minim stroke with a flag at the mid-point on the left side; the presence of flags towards the top of the minim stroke of the letters $\mathbf{b}, \mathbf{d}, \mathbf{h}$ and $\mathbf{l}$, which serves to create a notch or dovetail ; and the consistent use of the ligature -st.

${ }^{49}$ I am extremely grateful to Morex Arai, Reference Services Assistant at the Huntington Library, for confirming that the seal is not to be found among the twelve boxes of removed seals within the Egerton collection.

50 W.D. MACRAY, «The manuscripts preserved at the Bridgewater Trust Office, Walkden, Lancashire ", in Historical Manuscripts Commission, appendix to the Eleventh Report, part VII. The
} 
only a handful of abbatial seals survive for Savigny, and while the « hand-and-staff » motif of Abbot Richard's device is not unusual as far as contemporary Cistercian practices are concerned ${ }^{51}$, it is the only known Savigny seal to bear this particular motif. As to whether its design represented a continuation or a departure from those seals used by Richard's predecessors, we are unfortunately unable to say, although it is possible that, like the offices discussed above, and the abbey's new scriptorium of the early 1160 s, the introduction of this typically Cistercian device is something we should attribute to Prior Theobald ${ }^{52}$.

Whatever the case may be, had Richard's seal survived it would not only be the oldest known example from Cistercian Normandy, but also one of the oldest for Cistercian France $^{53}$. As it is, the 19th-century description allows us to push back previous estimates of the use of an abbatial seal at Savigny by almost twenty-five years ${ }^{54}$. As for the oldest surviving Savigny seal, and by extension one of the oldest of Cistercian Normandy, this is attached to a charter housed today at the London Metropolitan Archives (Appendix, $\mathbf{n}^{\mathbf{0}} \mathbf{3}$ ). Issued in relation to a donation made by a canon of $\mathrm{St}$

manuscripts of the Duke of Leeds, the Bridgewater Trust, Reading Corporation, the Inner Temple, etc., London, HMSO, 1888, p. 142.

51 D. Williams, «Medieval Cistercian seals with special reference to 'hand-and-staff' seals », Archaeologia Cambrensis, 154, 2005, p. 153-178.

${ }^{52}$ For Prior Theobald and the new scriptorium, see R. ALLEN, « À la recherche... », op. cit., p. 41-42.

${ }^{53}$ The only known « hand-and-staff » Cistercian seals to predate Abbot Richard's come from Clairvaux (c.1144) and Ourscamp (1154) : D. WILLIAMS, « Cistercian seals... », op. cit., p. 161.

${ }^{54}$ For previous discussion, which attributed the first Savigny seal to Abbot Simon (1179-1184/5), see C. MAUduIt, «Sceaux et pratiques sigillaires abbatiales en Normandie, XII $-\mathrm{XIII}$ e siècles », in C. Blanc-RIEhl, J.-L. ChaSSel and C. MANeUVRIER (dir.), Apposer sa marque..., op. cit., forthcoming. 
[fichier séparé Allen_Fig._1]

Fig. 1 Charter of Richard de Courcy, abbot of Savigny, concerning the affiliation of St Mary's, Dublin with the abbey of Buildwas

(San Marino, California, Huntington Library, EL/550) 


\begin{tabular}{|c|c|c|}
\hline Act & Author & Date \\
\hline $1147-1157$ & William, earl of Gloucester & Arch. nat., L 976, $\mathrm{n}^{\circ} 1165$ \\
\hline $1147-1157$ & William de Saint-Clair & $\begin{array}{l}\text { Arch. dép. Calvados, F 5690, } \\
\text { fol. 146v }\end{array}$ \\
\hline c. 1148 & Hugh d'Amiens, archbishop of Rouen & Arch. nat., L 970, n 529 \\
\hline c. 1148 & Hugh d'Amiens, archbishop of Rouen & Arch. nat., L 970, n $^{\circ} 532$ \\
\hline c. Nov 1148 & Hugh d'Amiens, archbishop of Rouen & Arch. nat., L 970, n 530 \\
\hline c. Nov 1148 & Hugh d'Amiens, archbishop of Rouen & Arch. nat., L 970, n $^{\circ} 531$ \\
\hline 1148 & Conan III, duke of Brittany & Arch. nat., K 23, $\mathrm{n}^{\mathrm{o}} 15^{8}$ \\
\hline $1150 / 1$ & Geoffrey, count of Anjou & Arch. nat., L 969, nº 399 \\
\hline $1150 / 1$ & $\begin{array}{l}\text { William de Passavant, bishop of Le } \\
\text { Mans }\end{array}$ & BnF, ms lat. 9215, $\mathrm{n}^{\circ} 94$ \\
\hline 1150 & Henry de Fougères & Arch. nat., L 968, nº 206 \\
\hline 1150,12 Aug & Robert, bishop of Exeter & Arch. nat., L 967, $\mathrm{n}^{\circ} 90$ \\
\hline $1151-1153$ & Henry II, king of England & Arch. nat., L 976, $\mathrm{n}^{\circ} 1156$ \\
\hline $1151-1153$ & Bernard, abbot of Clairvaux & $\begin{array}{l}\text { Arch. dép. Calvados, F 5690, } \\
\text { fol. 130v }\end{array}$ \\
\hline 1151 & Ralph II de Fougères & Arch. nat., L 973, $\mathrm{n}^{\circ} 766$ \\
\hline 1153, 19 Sep & Alan, bishop of Rennes & Arch. nat., L 968, n 207 \\
\hline $1153,19 \mathrm{Sep}$ & Alan, bishop of Rennes & Arch. nat., L 977, $\mathrm{n}^{\circ} 1255$ \\
\hline $1154 / 5$ & Guido the forester & Arch. nat., L 967, nº 93 \\
\hline$[1154$, n. st. $]$ & Hugh d'Amiens, archbishop of Rouen & $\begin{array}{l}\text { Arch. dép. Calvados, F 5690, } \\
\text { fol. 132v }\end{array}$ \\
\hline 1154 & Conan de Châteaugiron & Arch. nat., K 23, $n^{\circ} 23^{6}$ \\
\hline 1155,20 June & Alan, bishop of Rennes & Arch. nat., L 977, $\mathrm{n}^{\circ} 1275$ \\
\hline 1155, Oct & Ralph II de Fougères & $\begin{array}{l}\text { Rouen, Bibl. mun., ms Leber } \\
5636, \mathrm{n}^{\circ} 3\end{array}$ \\
\hline $1155,1 \mathrm{Dec}$ & Odo II, duke of Brittany & Arch. nat., K 23, $\mathrm{n}^{\circ} 23^{9}$ \\
\hline 1155,6 Dec & Odo II, duke of Brittany & Arch. nat., K 23, $n^{\circ} 23^{10}$ \\
\hline $1156,26 \mathrm{Nov}$ & Richard de Courcy, abbot of Savigny & $\begin{array}{l}\text { San Marino, California, } \\
\text { Huntington Library, EL/550 }\end{array}$ \\
\hline $1156 / 7$ & Richard de Bohon, bishop of Coutances & Arch. nat., L 973, n ${ }^{\circ} 780$ \\
\hline 1157 & Ralph II de Fougères & Arch. nat., L 975, $\mathrm{n}^{\circ} 1071$ \\
\hline 1157, March & Geoffrey, son of Geoffrey de Clinton & Arch. nat., L 969, no 339 \\
\hline 1157, 16/17 June & Peter de Saint-Hilaire & $\begin{array}{l}\text { BnF, ms nouv. acq. lat. 2292, } \\
n^{\circ} 1\end{array}$ \\
\hline $1157,16 / 17$ June & Peter de Saint-Hilaire & $\begin{array}{l}\text { BnF, ms nouv. acq. lat. 2292, } \\
\mathrm{n}^{\circ} 2\end{array}$ \\
\hline 1157,26 Aug & Stephen, bishop of Rennes & Arch. nat., L 972, $\mathrm{n}^{\circ} 665$ \\
\hline
\end{tabular}

Table 2 Original charters of the abbey of Savigny, 1147-115755

\footnotetext{
${ }^{55}$ This list does not include papal bulls.
} 
Paul's, London, the act concerns the Savigniac house of Stratford Langthorne, and was sealed by Peter, abbot of Quarr, and Jocelin, abbot of Savigny. Peter's seal has since been destroyed, but Jocelin's, which has not before been noticed by those with an interest either in Savigniac or Cistercian seals, is almost perfectly preserved (fig. 2). Of white wax, which has been varnished brown, it is oval in shape and measures $400 \mathrm{~mm}$ in height and $260 \mathrm{~mm}$ wide. The field shows the abbot in his vestments, seated, holding a pastoral staff in his left hand (the crook turned away) and a book in his right. Like Abbot Richard's device, the field is surrounded by the legend + SIGILLVM ABBATIS SAVIGNEII.

Unfortunately, while it is relatively easy to set the seal within its iconographical context, determining the precise (or even approximate) date at which this charter was issued is somewhat more complicated. Of those who witnessed the act, only Abbot Jocelin's tenure in office can be dated with any precision, setting a terminus a quo of $1165^{56}$. Peter, abbot of Quarr, is said by some to have been succeeded by $c .1171^{57}$, but others

\footnotetext{
${ }^{56}$ According to the so-called Chronicon Savigniacense, Jocelin retired from his seat in 1178, having reigned for sixteen years (R. ALLEN, «The annals and history... », op. cit., p. 70). His predecessor, William II, was still in post in 1165, however, since a charter of Rotrou, archbishop of Rouen (11651183), is addressed to him (Paris, Arch. nat., L 974, $\mathrm{n}^{\circ}$ 988). It is possible that the author of this part of the Chronicon, who was writing in the mid-13th century, and may have been working from another text, now lost, mis-transcribed the Roman numeral for thirteen (xiii) by joining the first two minims together to form the numeral for sixteen $(x v i)$.

${ }^{57}$ A. Morey and C.N.L. Brooke, Gilbert Foliot and his letters, Cambridge, Cambridge University Press, 1965, p. $280 \mathrm{n} .1$, but this is based on the appearance of Gervase, abbot of Quarr, in a charter that others have dated to 1129 - 1150 (The heads of religious houses, England and Wales. 1, 940-1216, D. Knowles, C.N.L. Brooke and V. London (ed.), 2nd ed., Cambridge, Cambridge University Press, 2001, p. 139).
} 
[fichier séparé Allen_Fig._2]

Fig. 2 The seal of Jocelin, abbot of Savigny

(London Metropolitan Archives, CLC/313/A/MS 25121/1354) 
have suggested he was still in office by $1186^{58}$. Hugh the dean, who is presumably Hugh de Mareni, dean of St Paul's, was in office from $1157 / 8$ to $1179 / 80^{59}$. He was a kinsman of Richard de Belmeis I, bishop of London (1108-1127), as was Richard Junior, who also appears among the witnesses. Richard became Prebend of Holborn c. $1167^{60}$, and since the charter does not expressly identify him as such, it may have been issued before this date ${ }^{61}$. It seems fairly certain that Abbot Jocelin witnessed the act in England, as he did another charter concerning the abbeys of Margam and Neath, which likewise seems to have been issued in $1165-1167^{62}$. What brought Jocelin across the Channel is unclear, but it is not impossible that, as the newly elected abbot of Savigny, and like Abbot Serlo before him, he had come to conduct a visitation of the filiation's British houses ${ }^{63}$.

If Jocelin did append his seal to the St Paul's act at sometime between 1165 and 1167 then it is not just the earliest known Savigny seal to survive, but also the earliest for

${ }^{58}$ The charters of Quarr Abbey, S.F. HOCKEY (ed.), Isle of Wight, Isle of Wight County Record Office, 1991, p. 112. This date is given without full explanation.

${ }^{59}$ Fasti ecclesiae Anglicanae 1066-1300 : I, St Paul's, London, D. GREENWAY (ed.), London, University of London, 1968, p. 5.

${ }^{60}$ C.N.L. BROOKE, London, 800-1216 : The shaping of a city, London, Secker and Warburg, 1975, p. 346.

${ }^{61}$ Diana Greenway dates the St Paul's charter 1164 - 1171, with the terminus ad quem being the end of Peter of Quarr's abbacy (D. GREENWAY (ed.), Fasti ecclesiae..., op. cit., p. 53).

${ }^{62}$ Cartee et alia munimenta quae ad dominium de Glamorgan pertinent, G.T. Clark (ed.), 6 vol., Cardiff, 1910, t. I, p. 152-153. The act records an agreement reached before Jocelin and Walter, abbot of Combermere. For the terminus ad quem, see D. KNOwLES, C. BrooKE and V. LONDON (ed.), Heads 940-1216..., op. cit., p. 130.

${ }^{63}$ For Serlo's visit to England in 1150, see The foundation history of the abbeys of Byland and Jervaulx, J. BURTON (ed.), York, University of York, Borthwick Institute for Archives, 2006, p. 44 n. b. 
Cistercian Normandy. Its closest contemporary exists today in a fragmentary form, and was appended by Simon, abbot of Saint-André-en-Gouffern (1171-1179), to an act of Froger, bishop of Sées $(1159-1184 / 5)$, dated $1174^{64}$. The image on the field is now quite badly worn, but it shows an abbot, bare-headed and standing, dressed in a chasuble. The hands are no longer visible, but, according to a 19th-century description, they once held a pastoral staff in the left and an open book in the right. Likewise, the legend is now almost illegible, but it once read [+] SIGI[LLVM ABBAT]IS S(an)C(t)I AND[RE]E ${ }^{65}$.

As for Jocelin's seal, if it bears much in common with that of Abbot Simon, who would himself rise to become abbot of Savigny in 1179, its iconography stands in contrast to that employed by Abbot Richard de Courcy. Two abbots - Alexander of Cologne (1158-1161) and William II (1161/2-1165) - governed Savigny in the interim, but it is impossible to say whether they were responsible for the move away from the « hand-and-staff» motif, since neither trace nor mention of their seals has survived. Whatever the case may be, the design of Jocelin's seal, which serves to emphasise the authority invested in the abbot's office, was certainly in keeping with contemporary Cistercian practices ${ }^{66}$. Moreover, abbots of Savigny continued to use

\footnotetext{
${ }^{64}$ Caen, Arch. dép. Calvados, H 9090 (formerly H non coté 70, fonds du Plessis-Grimoult, carton 8/2).

${ }^{65}$ G. DemaY, Inventaire des sceaux de la Normandie recueillis dans les dépôts d'archives, musées et collections particulières ... de la Seine-inférieure, du Calvados, de l'Eure, de la Manche et de l'Orne, Paris, Impr. nationale, 1881, $\mathrm{n}^{\circ} 2858$.

${ }^{66}$ E. RousSEAU, «Les sceaux des cinq premières maisons de l'ordre de Cîteaux (1098-1516) », École nationale des chartes, positions des thèses..., 1996, p. 259-265, at p. 263 ; ID., « Les cisterciens », in J.-L. Chassel (dir.), Sceaux et usages de sceaux dans la Champagne médiévale, Paris, Somogy, 2003, p. $85-89$, at p. $85-86$.
} 
the same design well into the 13th century, to the extent that such is the similarity between Jocelin's seal and those of abbots Gerard (1186-1187) and William IV de Douvres (1187/8-1207) as to suggest that they may have been pressed from the same matrix ${ }^{67}$, implying that this was passed from one abbot to the next, rather than being destroyed upon each abbot's death. A fragment of Abbot Ralph's (1208-1221) seal suggests that he may have also used the same matrix, although sadly not enough of the impression survives to be certain ${ }^{68}$. Even so, it is only with the arrival of Stephen of Lexington (1229-1243) that we can detect a noticeable change in the design of the abbot of Savigny's seal ${ }^{69}$.

As for the seals attached to the British Library charter roll, which are both now fragmentary in their form, neither belonged to the abbot of Savigny. It is nevertheless worth briefly returning to the roll itself, for although its last three acts do not contain

\footnotetext{
${ }^{67}$ Caen, Arch. dép. Calvados, H 1781 (Abbot Gerard) ; Kew, The National Archives, DL 27/27 (Abbot William). William's seal is not among those catalogued in C. MAUDUIT, « Sceaux et pratiques... », op. cit., forthcoming. Gerard's seal is inventoried in G. DEMAY, Inventaire des sceaux..., op. cit., $\mathrm{n}^{\circ} 2878$, although this incorrectly supplies the last word as SAVIGNEN'. A somewhat fanciful drawing can be found in A.-L. LÉCHAUDÉ D'ANISY, Extrait des chartes, et autres actes normands ou anglo-normands, qui se trouvent dans les archives du Calvados, 2 vol. and atlas, Caen, Chez l'auteur, 1834-1835, Atlas, planche IV, $\mathrm{n}^{\circ} 10$.

${ }^{68}$ Paris, Arch. nat., L 972, $\mathrm{n}^{\circ}$ 691. The surviving fragment shows only the abbot's legs and the arms of the throne on which he is sitting, which have the same pronounced nodule at their end as on the seals of abbots Jocelin, Gerard and William IV.

${ }^{69}$ Only mouldings of this seal, which was oval and depicted the abbot, standing, holding a book in his left hand and a pastoral staff in his right (the crook turned in), surrounded by the legend + S' ABBATIS DE SAVIGNEIO, survive : Paris, Arch. nat., SC/N 2879 ; Ibid., SC/D 9090 (once attached to Ibid., L $\left.969, \mathrm{n}^{\circ} 361\right)$
} 
the same detailed witness lists as the first two, they still help shed light on certain issues that have not before been examined in any detail. Moreover, all three acts, although containing no dating clauses, can be dated with some precision. The third act, for example, must have been issued by Abbot William III de Toulouse in 1178, the year in which he became abbot of Savigny ${ }^{70}$, and at some point in this year before 29 July, the day on which Alexander, abbot of Cîteaux (1168-1178), author of the roll's fourth act confirming that issued by William, is said to have $\operatorname{died}^{71}$. Abbot William's charter claims that the issue it resolves, namely a dispute between Matthew, abbot of Basingwerk, and Ranulf, abbot of Buildwas (1155-1187), was first raised at a meeting of the Cistercian chapter (in capitulo Cisterciensi), which is almost certainly a reference to the general chapter meeting held in September $1177^{72}$. The matter was then brought before the chapter of Savigny itself (auditis itaque in capitulo Savignei), where the dispute was decided in favour of the abbot of Buildwas. The witness list of William's act records the names of Savigny figures only, including that of a previously unknown prior $^{73}$. We know, however, that other figures from the Savigniac

\footnotetext{
${ }^{70}$ R. ALLEN, « The annals and history... », op. cit., p. 71.

${ }^{71}$ C. EnRIQUeZ, Menologium Cistertiense notationibus illustratum, Anvers, 1630, p. 245. Alexander is
} often said incorrectly to have died in 1175 . For discussion, and the correct year of 1178 , see Y. CONGAR, «Henry de Marcy, abbé de Clairvaux, cardinal-évêque d'Albano et légat pontifical », Analecta Monastica, 5, 1958, p. 1-90, at p. 10.

${ }^{72}$ Sadly, the statutes of the 1177 reunion do not survive, although we know a meeting took place, since Gervase of Canterbury preserves a letter sent to the chapter by Raymond, count of Toulouse (GERVASE OF CANTERBURY, Chronica, in The historical works of Gervase of Canterbury, W. STUBBS (ed.), 2 vol., London, Longman and Co., 1879-1880, t. I, p. 270-271).

${ }^{73}$ Prior Robert was succeeded at some time after June 1179 - 1180/1 by Renaud de Caen (BnF, ms nouv. acq. lat. 1022, p. 266-268), who also features among the witnesses of Abbot William's act. Renaud was in post until 1182/3, when he was succeeded by Prior William (Päpstliche 
filiation were also present, since William's charter records that his ruling was made before Walter, abbot of Neath (c.1178-c.1196), and Moses, abbot of La Vieuville ${ }^{74}$. Abbot Walter is also one of seven Savigniac abbots named among the witnesses of the charter issued by Alexander of Cîteaux confirming William's ruling, and since this act must have been issued before 29 July 1178, its witness list allows us to make a number of important observations.

The first concerns the Savigny general chapter. According to his vita, it was Abbot Geoffrey de Bayeux who was responsible for instigating an annual meeting of the Savigniac abbots, which was to be held for three consecutive days from the feast of the Trinity ${ }^{75}$. If, however, those with an interest in the history of Savigny have long been aware of this fact, finding evidence of these meetings, of which no statutes survive, has proved more difficult. The abovementioned vita claims that reunions of the general chapter were held «until the time of [Abbot] Serlo $»^{76}$, a statement confirmed by the record of two meetings in 1141 and $1147^{77}$, but the vita also seems

Delegationsgerichtsbarkeit in der Normandie : 12. und frühes 13. Jahrhundert, H. MÜLLER (ed.), 2 vol., Bonn, Bouvier, 1997, t. II, nº 63).

${ }^{74}$ La Vieuville, Ille-et-Vilaine, cant. Dol-de-Bretagne, cne. Epiniac. Moses is said by the editors of the Gallia Christiana to have been elected in 1179 (Gallia Christiana in provincias ecclesiasticas distributa, 16 vol., Paris, Firmin Didot, 1865-1899, t. XIV, col. 1080), but William's act shows that he was already in post by 1178 . His last known occurrence is in 1183 .

${ }^{75}$ For the establishment of the Savigny general chapter, see G. CONSTABLE, «The affiliation of Savigny... », op. cit., p. 56.

${ }^{76} « \ldots$ usque ad tempus B. Serlonis ... » : E.-P. SAUVAGE, «Vitae BB. Vitalis et Gaufridi... », op. cit., p. 405 .

${ }^{77}$ J. BURTON (ed.), Foundation of Byland..., op. cit., p. 9, 41. 
to suggest that such things were discontinued following the merger with Cîteaux ${ }^{78}$. Elsewhere, a letter of Aelred, abbot of Rievaulx (1147-1167), addressed to Lambert, abbot of Cîteaux (1155-1161), not only refers to a meeting of the Savigny general chapter held during the reign of Gerald, abbot of Byland (1135-1142), but was itself born of another general chapter, although it is unclear whether this was one of Savigny or of Cîteaux ${ }^{79}$.

Whatever the case may be, the acts of Abbot William and Abbot Alexander show that the heads of at least ten Savigniac houses from throughout France, England and Wales came together at Savigny at some point in 1178 before 29 July. The question that remains, of course, is whether this was a meeting of the general chapter. Sadly, neither act refers to the gathering as such, stating simply that discussions were held in capitulo. We know, moreover, that it was not unheard of for Cistercian abbots to meet in relatively large numbers outside of a general chapter, as evidence from the cartulary of Morimond makes clear ${ }^{80}$. But the gathering at Savigny was no ordinary

\footnotetext{
${ }^{78}$ This is the version of the vita as preserved by Arthur du Monstier (manuscript $M$ in Sauvage's edition), rather than that by Dom Claude Auvry (manuscript $S$ ), which simply notes that the general chapter was « diligently observed throughout Geoffrey's time and thereafter since » (quod quidem toto suo tempore et deinceps diligenter est observatum): E.-P. SAUVAGE, «Vitae BB. Vitalis et Gaufridi... », op. cit., p. 405.

${ }^{79}$ J. BURTON (ed.), Foundation of Byland..., op. cit., p. 28-32. Another version of this letter, which unfortunately does not help clarify matters, is to be found among the Savigny charters at Paris (Arch. nat., L 967, $\mathrm{n}^{\text {os }} 130$ and 131). For an imperfect transcription, see J. BUHOT, «L'abbaye de Savigny... », op. cit., p. $18-19$.

${ }^{80}$ In early 1154, the abbot of Morimond (Haute-Marne, cant. Bourbonne-les-Bains, cne. Parnoy-enBassigny) was to be found at Morimond alongside abbots from seven of his daughters, namely La Crête (Haute-Marne, cant. Bologne, cne. Bourdons-sur-Rognon), Ebrach (Bayern), Kamp (Nordrhein-
} 
meeting. After all, the act of Abbot Alexander makes it clear that he was himself present. Of course, this alone is not enough for us to claim that the abbots had gathered together in general chapter. But, turning once again to the witness list of Abbot William's act, we find there the recently-retired Abbot Jocelin (Josleno qui ibi fuerat abbas). His retirement is recorded by one other source, namely the so-called Chronicon Savigniacense, which claims it took place «after the general chapter » in $1178^{81}$. Dom Claude Auvry interpreted this as a reference to the Cistercian general chapter of this year ${ }^{82}$, but was unaware of the existence of the acts of abbots William and Alexander.

Thus, unless we wish to re-date Abbot Jocelin's retirement to September 1177, it would appear that the third and fourth acts of the charter roll preserve for us the record both of a meeting of the Savigny general chapter and a snapshot of those who were present. Besides allowing us to date the acts in question with some precision, the implications of these findings are important for a number of reasons. In the first instance, even if one wished to see in these acts nothing more than evidence of an extraordinary meeting of Savigniac abbots, rather than a general chapter, they still

Westfalen), Walkenried (Niedersachsen), Villers-Bettnach (Moselle, cant. Le Pays messin, cne. SaintHubert), Clairefontaine (Haute-Saône, cant. Port-sur-Saône, cne. Polaincourt-et-Clairefontaine), Bithaine (Haute-Saône, cant. Lure-1, cne. Adelans-et-le-Val-de-Bithaine), and Theuley (Haute-Saône, cant. Dampierre-sur-Salon, cne. Vars) : Recueil des chartes de l'abbaye de Morimond au XII siècle, $\mathrm{H}$. FLAMMARION (ed.), Turnhout, Brepols, 2014, nº 18, p. 146-147.

${ }^{81}$ « Anno vero Domini $. \mathrm{M} .{ }^{\circ} \mathrm{C} .{ }^{\circ} \mathrm{LXXVIII}{ }^{\circ}$, abbas Joslenus post capitulum generale cessit » : R. ALLEN, « The annals and history...», op. cit., p. 71.

${ }^{82}$ C. AUvRY, Histoire de la congrégation de Savigny, A. LAveILle (ed.), 3 vol., Rouen, A. Lestringant, 1896-1898, t. III, p. 228. 
preserve for us the record of a heretofore unnoticed visit to Savigny by an abbot of Cîteaux ${ }^{83}$. Alexander had previously been abbot of Savigny, and while affection for his old house cannot be ruled out as a motivating factor, it is more likely he had come to oversee the aforementioned retirement of Abbot Jocelin ${ }^{84}$. Whatever the reason behind Alexander's visit, his decision to travel to south-western Normandy is one that may have shaped abbatial succession at both Savigny and Cîteaux. It is perhaps no coincidence that Alexander died shortly after his visit to his former house, and it is even possible that it was during the lengthy return journey to Burgundy, which even by the most optimistic estimates would have taken more than a week ${ }^{85}$, that the abbot of Cîteaux experienced some misfortune that led to his death. His eventual successor at Cîteaux was none other than William de Toulouse, abbot of Savigny ${ }^{86}$, who was himself succeeded by Simon, abbot of Saint-André-en-Gouffern, another attendee of the 1178 meeting.

As for the final act, it too was most likely issued as the result of a general chapter, although this time one of the Cistercian Order. Addressed to William III, abbot of

${ }^{83}$ I am grateful to Professor Janet Burton for sharing with me her thoughts on the unusualness of Alexander's participation in the Savigny (general) chapter (pers. corr. 26 October 2017).

${ }^{84}$ As is shown by the example of Serlo de Vaubadon, who tried to retire in 1147 (H. FEISS, R. PEPIN and M. O'BRIEN, Monastic reformers..., op. cit., p. 31), the process by which an abbot left his post while living involved the consent of multiple authorities.

${ }^{85}$ The abbey of Savigny was $480 \mathrm{~km}$ from Cîteaux (as the crow flies), meaning that, even at an average of $60 \mathrm{~km}$ per day, the journey would have taken over eight days. For medieval travel times, see N. OHLER, The medieval traveller, trans. C. HILliER, Woodbridge, Boydell Press, 2010, p. 97-101.

${ }^{86}$ The monks of Cîteaux had originally wanted to elect Henry de Marcy, abbot of Clairvaux (11771179), but he declined and was subsequently elected cardinal-legate at the Third Lateran Council in March 1179 : Y. CONGAR, «Henry de Marcy... », op. cit., p. 25. 
Cîteaux (1190-1194), it is broadly dated by the election of William of Pershore, abbot of Stoneleigh (c.1189-1199) ${ }^{87}$, and the deaths of the abbots of Combe and Merevale. The act itself is simple in form, and merely confirms to Abbot William that the four preceding acts on the roll are true copies of the originals. The statutes of the 1192 Cistercian general chapter record that the abbots of Savigny and Clairvaux were appointed to resolve a dispute between the abbots of Basingwerk and Buildwas, and, although the cause is not given ${ }^{88}$, it seems most likely that it concerned their affiliation ${ }^{89}$. As such, it would be within reason to conclude that the abbots of Savigny and Clairvaux subsequently delegated the task of confirming matters to their three English counterparts, all of whom, as heads of houses within the Cîteaux filiation ${ }^{90}$, could be seen to be impartial in relation to a dispute within the order's Savigniac/Claravallian branch.

Although the dispute between Basingwerk and Buildwas may have rumbled on to at least $1195^{91}$, the charter roll of late 1192 is the last document to deal with it in any

\footnotetext{
${ }^{87}$ Although the abbreviation de Stanl' used by the scribe has been identified elsewhere as relating to the Savigniac abbey of Stanley (D. WiLliAMS, «Basingwerk Abbey... », op. cit., p. 90), its abbot at this time was called Nicholas (c.1180-1205). The abbreviated form de Stanl' for Stoneleigh is unusual, but not unheard of (English episcopal acta 14. Coventry and Lichfield, 1072-1159, M.J. FRANKLIN (ed.), Oxford, Oxford University Press, 1997, nº 62).

${ }^{88}$ Twelfth-century statutes from the Cistercian general chapter, C. WADDELL (ed.), Brecht, Cîteaux, 2002, p. 243.

${ }^{89}$ This is the conclusion reached by D. WiLliAMS, « Basingwerk Abbey... », op. cit., p. 90.

${ }^{90}$ The abbeys Combe (daughter of Waverley), Merevale and Stoneleigh (both daughters of Bordesley) all belonged to filiation of L'Aumône, eighth daughter of Cîteaux.

${ }^{91}$ A statute of the 1195 Cistercian general chapter records that the abbot of Savigny was ordered to make enquiries regarding an unspecified problem at Basingwerk (C. WADDELL (ed.), Twelfth-century
} 
detail. It is also one of the last surviving records of interaction between Savigny and its British houses. As Béatrice Poulle noted over twenty years ago, the conquest of Normandy by Philip Augustus (1180-1223) in 1204 served all but to sever links between Savigny and its daughters located across the Channel, even if the election of Englishmen such as Stephen of Lexington showed it was still able to attract men with connections there ${ }^{92}$. As such, the importance of the charter roll, and of the other documents discussed in this article, is not limited to the light they shed on the various issues discussed above. They also stand as important witnesses to a particular period in the history of the Savigniac filiation, and of the wider Cistercian order of which it was a part, which came to an end a little over a decade after the abbots of Stoneleigh, Combe and Merevale set their seals to the charter roll of late 1192. This period has certainly not lacked for scholarly attention, but the examination of the three documents in this article has shown, it is hoped, that it is worthy of further study, both with regards to the history of the Savigniac filiation in the British Isles and that of the abbey of Savigny itself.

statutes..., op. cit., p. 341), which some have interpreted as a reference to the dispute concerning its affiliation with Buildwas (D. WiLliAMS, « Basingwerk Abbey... », op. cit., p. 90).

${ }^{92}$ B. Poulle, « Savigny and England... », op. cit., p. 167. 


\section{Appendix}

$\mathbf{N}^{0} 1$.

[1190 - 1192, perhaps 1192].

Charter roll with five acts concerning the affiliation of the abbeys of St Mary's, Dublin, and Basingwerk, with the abbey of Buildwas. [1] Richard [de Courcy], abbot of Savigny, notifies Ranulf, abbot of Buildwas, that the abbey of St Mary's, Dublin, is henceforth to be administered by the abbey of Buildwas, according to the ordo of the abbey of Cîteaux. Date: 26 November 1156 ; [2] Richard [de Courcy], abbot of Savigny, notifies the abbots and houses belonging to the church of Savigny that he has granted the abbey of Basingwerk as a daughter house to the abbey of Buildwas, which shall govern it according to the ordo of Cîteaux. Date: 1157; [3] William [III de Toulouse], abbot of Savigny, notifies the abbots of [the filiation of] Savigny that a disagreement arose at the Cistercian [general] chapter between Matthew, abbot of Basingwerk, and Ranulf, abbot of Buildwas. The matter was thus brought before a meeting of the Savigny chapter, which examined the charters issued by Abbot Richard de Courcy in relation to the affiliation of the abbeys of Basingwerk and Dublin with that of Buildwas. In the presence of Walter, abbot of Neath, and Moses, abbot of La Vieuville, it was ruled that Abbot Ranulf should continue to administer the abbeys of Basingwerk and Dublin as daughter houses, and that their abbots should continue to obey him in all matters. Date: [1178, c. 4 June] ; [4] Alexander, abbot of Cîteaux, confirms the abbeys of Basingwerk and Dublin to the abbey of Buildwas, according to the charters of abbots Richard de Courcy and William de Toulouse. Date : [1178, c. 4 
June] ; [5] W[illiam] I, abbot of Combe (1183-1192), W[illiam], abbot of Merevale (d. 1192), and William [of Pershore], abbot of Stoneleigh, write to W[illiam III], abbot of Citeaux, to confirm that the four charters above, which were presented to them by H., abbot of Buildwas, are true copies of the originals. Date : [1190 - 1192, perhaps 1192].

A. London, British Library, Add. Roll 8075. Approx. $115 \times 470 \mathrm{~mm}$. No medieval endorsements. Sealed sur double queue; two seals (damaged and repaired) and tags remain ${ }^{93}$, third seal and tag missing.

a. J. HUNTER, Ecclesiastical documents..., op. cit., no III, p. 51-54 (from A). - b. M. BIGELOW, Placita anglo-normannica : law cases from William I to Richard I : preserved in historical records, Boston, Little, Brown, and Co., 1879, p. 226-228 (from a).

Note. The dates of the first two acts are given by the texts themselves. For the dating of the third, fourth and fifth acts see above.

[1] Venerando fratri et amico Rannulfo abbati de Billewas ejusdemque loci conventui, frater Ric(ardus) dictus abbas et conventus Savignei, salutem et dilectionem. In nomine domini nostri Jhesu Christi committimus atque concedimus vobis et domui vestre curam et dispositionem domus nostre Sancte Marie Dubline inperpetuum habendam ; ut vos et domus vestra, secundum tenorem ordinis Cist(er)ciens(is), curam

\footnotetext{
${ }_{93}$ Only fragments of these seals remain. The first, which was round, shows a hand holding a pastoral staff (the crook turned away). Of the legend remains : + SIGILL[VM] ABBA[TIS] ... . The second, which was oval, shows an abbot, standing. Of the legend only the letters ABB... remain.
} 
ejusdem domus quasi filie vestre et a vobis egresse, in omnibus et per omnia habeatis; et ipsa vobis et domui vestre tanquam matri sue juxta eundem tenorem ordinis Cist(er)cie(n)sis semper et ubique respondeat et obediat. Facta est autem hec nostra commissio atque concessio in communi capitulo Savignei, anno ab Incarnatione domini M. ${ }^{\circ}$ C. ${ }^{o} \mathrm{~L} \mathrm{VI}^{\mathrm{o}}$, sexto $\mathrm{k}(\mathrm{a}) 1$ (endas) decemb(ris). Teste : Arraudo priore, et Gauf(r)ido suppriore, et Unfrido cantore, et Rob(erto) et Guillelmo et Gaufrido, cellarariis, et Hugone sacrista, et Rob(er)to magistro novitiorum, et Hugone infirmario, et Christiano hospitali, et Guill(el)mo portario et universo capitulo. [2] ${ }^{(a)}$ Omnibus abbatibus atque conventibus ad ecclesiam Savignei pertinentibus, frater R. dictus abbas et conventus Savignei ${ }^{(b)}$, salutem. In nomine salvatoris nostri Jhesu Christi notum sit vobis omnibus prsesentibus atque futuris, quod nos concedimus inperpetuum ecclesie de Billewas et domino Ranulfo abbati atque conventui, abbatiam de Basinguers cum om $<\mathrm{n}>\mathrm{ibus}$ pertinentiis suis. Ita ut ecclesia de Buldewas ecclesie de Basingvec provideat atque subveniat in omnibus et de omnibus sicut mater filie secundum ordinem Cist(er)ciensem. Et ecclesia de Basinguerc ecclesie de Billewas respondeat et obediat in omnibus et de omnibus sicut filia matri juxta eundem ordinem. Facta est autem hec nostra concessio in capitulo Savignei anno ab Incarnatione domini M. ${ }^{o}$ C. ${ }^{o}$ L.VII ${ }^{o}$ Teste : Rog(er)o priore, et Gaufrido suppriore, Rob(er)to et Gaufrido, cellarariis, et Rob(erto) magistro novitiorum, et Hug(one) sacrista, Rog(er)o hospitali, et Hug(one) portar(io) et toto capitulo. [3] Frater ${ }^{(\mathrm{c})}$ Guill(elm)us Savignei dictus abbas, omnibus abbatibus ad Savign(eum) pertinentibus, salutem. Notum vobis facimus quod postquam audivimus abbatem Matheu(m) de Basinguec querimoniam fecisse in capitulo Cist(er)ciensi de abbate Ra(n)nulfo de Billewas, quod abbatias de Bas(inguec) et de Dublina quas per Savigneiu(m) habebat, contra formam ordinis teneret, utrisque mandavimus propter bonum pacis ut ante 
tempus capituli sequentis Savign(ei) se presentarent. Et ipsi sic fecerunt. Auditis itaque in capitulo Savign(ei) querelis et gravaminibus abbatis M. de Basing(uec) et responsis abbatis R. de Billewas et cartis quas in eodem capitulo ab abbate R. de $\mathrm{Curci}^{94}$ et conventu suo de predictis abbatiis transactis plusquam XX. annis acceperat, dignum duximus cum abbatibus qui aderant et cum senioribus nostris secretius inde tractare. Tunc rogavimus eos ut se ex toto consilio nostro et providentie committerent, et consenserunt. Nos autem, illis remotis, considerantes discrecionem et prudentiam antecessorum nostrorum qui prefatas abbatias abbati R. et conventui de Billew(as) tradiderunt et cartis confirmaverunt, propter necessarias causas et utiles dignum judicavimus quicquid super hec fecerunt ratum et firmum haberi inperpetuum. Pace igitur inter eos reformata in communi capitulo nostro presentibus abbatibus Galt(er)o de Neht et Moyse de Vet(er)i Villa commendavimus abbati R. de Bill(ewas) omnem curam et ordinationem predictarum domorum, sicut filiarum suarum, sicut antecessores nostri prius commendaverant et ejus carte testantur. Injunximus quoque abbati M. de Bas(inguec) et abbati A. de Dublina ut ipsi et domus suae ex toto intendant et obediant abbati et domui de Buld(ewas), sicut filii patri et sicut filie matri. Facta sunt hec in capitulo Savignei abque ulla contradictione. Hiis testibus : Rob(erto) priore et suppriorel $^{(\mathrm{d})}$ Pet(r)o, et Steph(an)o de Furnesia ${ }^{95}$, Josleno qui ibi fuerat abbas, Rainaldo de $\mathrm{Cham}^{96}$ et toto capitulo. [4] Frater $^{(\mathrm{c})}$ A. dictus abbas Cist(ercii) omnibus abbatibus ad Cist(ercium) pertinentibus, salutem. Sciatis nos presenti carta nostra confirmasse abbati et conventui de Billewas abbatias de Basinguec et de Duvelina, sicut primum dilectus filius noster Ricard(us) de Curci cum esset abbas Savigneii et

\footnotetext{
${ }^{94}$ Either Courcy, Manche, cant. Coutances, or Courcy, Calvados, cant. Falaise.

${ }^{95}$ Furness (Lancashire).

${ }^{96}$ Caen, Calvados, chef-lieu de cant.
} 
postea venerabilis frater noster Guill(elm)us de Tolosa ${ }^{97}$ factus abbas ejusdem loci eas eis in capitulo Savigneii concesserunt et cartis suis confirmaverunt. Volumus itaque et statuimus quicquid super hec fecerunt ratum et firmum haberi inperpetuum. Hiis testibus : Ricardo abbate Belbec $^{98}$, Sim(one) abbate de Sancto And(r)ea ${ }^{99}$, Galt(er)o abbate de Neht, Joh(ann)e abbate de Agneto ${ }^{100}$, Girardo abbate de Lu(n)gvilers ${ }^{101}$, Joh(ann)e abbate de Joravalle ${ }^{102}$, Radulfo abbate de Chalochi ${ }^{103}$. [5] Reverendis dominis et patribus W. abbati de Cist(er)cio et ceteris abbatibus ibidem in spiritu sancto congregatis, W. abbas de Cumba et W. abbas de Mirival et W. abbas de Stanl(egh), salutem et sue humilitatis obsequium. Ad precavenda varia pericula que itinerantibus et maxime in navigatione possunt contingere visum est $\mathrm{H}$. abbati de Bildewas nostra potius testimonia quam sua vobis transmittere munimenta super subjectione domorum de Basingvers et Dublin. Nos itaque fraterne postulationi nostrum suffragium pro posse volentes impendere prenotata diligenter inspeximus et eandem quam ibi legimus formam vestre discretioni plenius adnotare curavimus. $\operatorname{Val}(\mathrm{e}) \mathrm{t}(\mathrm{e})$

(a) The start of this and the fourth act marked by a gallows-pole - (b) Corrected from Savinei by insertion of -g- in interline - (c) First two letters of frater in majuscules - (d) Sic, corr. supprior.

\footnotetext{
${ }^{97}$ Toulouse, Haute-Garonne, chef-lieu de cant. Despite this toponymic, William came from Caen (R. ALLEN, « The annals and history... », op. cit., p. 71).

98 Richard, abbot of Beaubec (†10 September 1198). Beaubec-la-Rosière, Seine-Maritime, cant. Gournay-en-Bray.

${ }^{99}$ Simon, abbot of Saint-André-en-Gouffern (1171-1179). La Hoguette, Calvados, cant. Falaise.

${ }^{100}$ John, abbot of Aunay (c.1178-c.1201). Aunay-sur-Odon, Calvados, chef-lieu de cant.

${ }^{101}$ Gerard II, abbot of Longvilliers (1177-c.1192). Longvilliers, Pas-de-Calais, cant. Étaples.

${ }^{102}$ John, abbot of Jervaulx (1149/50-c.1185). England, East Witton, North Yorkshire.

${ }^{103}$ Ralph, abbot of Chaloché (c.1178-c.1184). Chaumont-d'Anjou, Maine-et-Loire, cant. Angers-6.
} 
No 2.

1156, 26 November - Savigny, in chapter

Richard [de Courcy], abbot of Savigny, notifies Ranulf, abbot of Buildwas, that the abbey of St Mary's, Dublin, is henceforth to be administered by the abbey of Buildwas, according to the ordo of Citeaux.

A. San Marino, California, Huntington Library, EL/550. $187 \times 195 \mathrm{~mm}$, of which fold $30 \mathrm{~mm}$. No medieval endorsements. Sealed sur double queue; seal and tag missing.

Note. The parchment has suffered some minor damage, resulting in the loss of certain letters. These are supplied below in square brackets.

Venerando fratri et amico Rannulfo abbati de Bilduwas ejusdemque loci conventui, $\left.\right|^{1} \mid$ frater Ricardus dictus abbas et conventus Savigneii, salutem et dilectionem. In $\left.\right|^{2} \mid$ nomine domini nostri Jhesu Christi committimus atque concedimus vobis et domui vestre $\left.\right|^{3} \mid$ curam et dispositionem domus nostre Sanctę Mar[i]e Duline inperpetuum habendam; ut $\left.\right|^{4} \mid \operatorname{nos}^{(\mathrm{a})}$ et domus vestr[a], secundum tenorem ordinis [Ci]sterciensis, curam e[j]usdem domus $\left.\right|^{5}$ quasi filie vestre et sicut a vobis egresse, in omnibus et per omnia habeatis; et ipsa $\left.\right|^{6} \mid$ vobis et domui vestrę tanquam matri suę juxta eundem tenorem ordinis Cisterciensis $\left.\right|^{7} \mid$ semper et ubique respondeat et obediat. Facta est autem hec nostra commissio $\left.\right|^{8} \mid$ atque concessio in communi capitulo Savigneii, anno ab Incarnatione domini $\left.\right|^{9} \mid$ M. ${ }^{o}$ C. ${ }^{o} \mathrm{~L} \mathrm{VI}^{\mathrm{o}}$, sexto $\mathrm{k}(\mathrm{a}) \mathrm{l}(\mathrm{endas}) \operatorname{dece}(\mathrm{m}) \mathrm{b}($ ris $)$. Teste : 
Arraudo priore, et Gaufrido subpriore, et $\left.\right|^{10} \mid$ Unfrido cantore, et Rob(er)to et Guill(elm)o et Gaufrido, cellerariis, et Hugone sa- $\left.\right|^{11} \mid$-crista, et Rob(er)to magistro noviciorum, et Hugone infirmario, et Christiano $\left.\right|^{12} \mid$ hospitali, et Guill(elm)o portario et universo capitulo.

(a) First minim om. A. 
No 3.

[1165 - 1178, perhaps $1165-1167]$.

Notice that Nicholas son of Clement, canon of St Paul's, London, has restored to the abbey of St Mary, Stratford Langthorne, the land and houses near to the church of St Martin, Ludgate, which he had bought from them. The abbey is to hold them after his death, in return for annual payments to the canons of St Paul's and the nuns of Clerkenwell.

A. London Metropolitan Archives, CLC/313/A/MS 25121/1354. $232 \times 85 / 87 \mathrm{~mm}$, of which $20 \mathrm{~mm}$ fold (with wrapping tie). Endorsed : Carta Nicholai filii Clementis de .II. sol' annui redditus in parochia sancti Martini de Ludgate (s. xiii) ; 9 8.b (s. xiv). Sealed sur double queue ; two seals and tags remain ${ }^{104}$, third seal missing, tag remains.

B. London Metropolitan Archives, CLC/313/A/MS 25501, fol. 17r (transcript from $A$ in cartulary known as Liber A, s. xiii med).

a. Early charters of the cathedral church of St. Paul, London, M. GIBBS (ed.), London, Offices of the Royal Historical Society, 1939, $\mathrm{n}^{\circ} 169$ (from $\left.A\right)^{105}$.

\footnotetext{
${ }^{104}$ Seal 1 : Oval, impression $26 \times 40 \mathrm{~mm}$ in white wax varnished brown, obverse shows an abbot in his vestments, seated on a throne, holding a pastoral staff in his left hand (the crook turned away) and a book in his right. Legend : + SIGILLVM ABBATIS SAVIGNEII. No counterseal. - Seal 2 : Rounded oval (fragment), impression $23 \times$ approx. $30 \mathrm{~mm}$ in white wax varnished brown, obverse shows a head in profile (to the right). Legend : + EGO DILIG[O] ... DILIGO. No counterseal.

${ }^{105}$ A slightly different version of this act can be found in Cartulary of St Mary Clerkenwell, W.O. Hassall (ed.), London, Offices of the Royal Historical Society, 1949, nº 282.
} 
Notum sit cunctis fidelibus tam futuris quam presentibus, quod domnus Nicholaus filius Clementis canonicus sancti Pauli Lond', reddidit et concessit $\left.\right|^{1} \mid$ ęcclesię sancte Marię de Stratford' post decessum suum perpetuo possidere libere et quiete terram et domos que sunt juxta ęcclesiam sancti Martini de $\left.\right|^{2} \mid$ Lutgate quam videlicet terram emerat ante a monachis prenominate ęcclesie de Stratford', pro reddendo eis inde annuatim unam libram piperis, vel $\left.\right|^{3} \mid$ quinque denarios. Hanc igitur terram sicut dictum est, cum pertinentiis suis reddidit domnus Nichol(aus) pręfatis monachis eo tamen intuitu et tenore, ut $\left.\right|^{4} \mid$ singulis annis ęcclesia de Stratford' post decessum domini Nic(holai), reddat ${ }^{(a)}$ canonicis ecclesie sancti Pauli de terra illa duos solidos, et duos similiter $\left.\right|^{5} \mid$ solidos sanctimonialibus de Fonte clericorum. Horum autem solid(orum), duo reddendi sunt canonicis in anniversario domni Nic(holai), duo autem alii sancti- $\left.\right|^{6} \mid$-monialibus predictis, in circumcisione Domini. His test(ibus) : Jo(sleno) abbate Savigneii, Pe(tro) abbate de Q(ua)rraria, Hug(one) decano, Ro(berto) de Clifford', $\left.\right|^{7} \mid$ Ric(ardo) juvene, magistro Gaufr(ido), Ro(berto) clerico.

(a) reddidit $B$. 